\title{
Optimization, Production, Purification and Characterization of Anti-Cancer Enzyme L-Asparaginase From Marine Sarocladium kiliense
}

\author{
M.Bhargavi and R. Jaya madhuri \\ Department of Applied Microbiology, Sri Padmavati Mahila Visvavidyalayam,Tirupati, India
}

\section{ABSTRACT}

L-Asparaginase is an anti-cancer enzyme used in the treatment of acute lymphoblastic leukemia(ALL). Most of the ALL cases occur in children at the age of 0-14 years. L-Asparaginase is responsible for the hydrolysis of L-Asparagine into L-Asparatic acid and ammonia. Present work discusses about the Optimization, production, purification and characterization of L-Asparaginase enzyme from marine Sarocladium species. The L-Asparaginase obtained by several purification steps like crude enzyme, ammonium sulphate precipitation, dialysis and fast protein liquid chromatography (FPLC). The enzyme was characterized by effect of different temperatures, PH, substrate concentrations, metal ions, inhibitors, stability of purified enzyme in human serum, SDS-PAGE analysis and enzyme kinetics.

KEY WORDS: L-ASPARAGINASE, PRODUCTION, PURIFICATRION, SAROCLADIUM SPECIES AND CHARACTERIZATION.

\section{INTRODUCTION}

The effects of fastidious environmental conditions on marine and terrestrial micro flora differ from each other. The marine microorganisms should be able to stay alive and cultivate in water environment with low nutrition, high salinity and high stress in the sea (Sahu et al., 2007). Marine microorganisms are taxonomically varied genetically single and largely unknown (Manivasagan et al., 2013). A large variety of diseases and medical problems perform a challenging risk to human. Cancer is the king of maladies and most severe challenge encounter by biomedical scientists. The treatments and therapies are varying with different types of cancers. But, the cancer biologists constantly upgrade the anti tumor compounds for therapy (Sivagurunathan et al., 2012). Various

\section{ARTICLE INFORMATION}

Received 20th Oct 2020 Accepted after revision 15th Dec 2020 Print ISSN: 0974-6455 Online ISSN: 2321-4007 CODEN: BBRCBA

Thomson Reuters ISI Web of Science Clarivate Analytics USA and Crossref Indexed Journal

\section{Clarivate
Analytics}

NAAS Journal Score 2020 (4.31)

A Society of Science and Nature Publication,

Bhopal India 2020. All rights reserved.

Online Contents Available at: http//www.bbrc.in/

Doi: http://dx.doi.org/10.21786/bbrc/13.15/17 biological resources like plants and microbes having anti cancer property. It can be assured that a focused approach and combined attempts would definitely accelerate the development of new antitumor drugs to be exposed with improved efficiency (Bhatnagar et al., 2010).

In recent years enzymes gain a better importance in clinical research. L-Asparaginase is one of them which is broadly distributed in environment (Pieters et al., 2011). The L-asparaginase enzyme (L-asparagine amidohydrolase, E.C.3.5.1.1) is an amidase group enzyme, used for the conversion of L-asparagine to L-aspartic acid and ammonia (Alizera et al., 2011). The bacterial L-asparaginase treatment of leukemia, causes allergic reactions (Shah et al., 2010). Therefore, the innovation of a new L- asparaginase immunologically dissimilar from that of bacteria has been greatly desired. It has been examined that eukaryotic microorganisms like yeast and filamentous fungi (Nagarethinam et al., 2012).

Purification of the enzyme is an significant step for categorization of physical and biological properties. For its effective therapeutic use of any substrate; it must be free of any contaminants and impurities. The purification straegy mainly involved in cost and yield of a product is

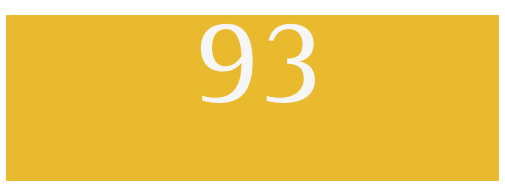


influenced by a number of sequential steps (Tundisi et al., 2017). Purification processing of biomolecules obtain from fermentation broths iscommon in biotechnology. Chromatographic techniques are widely used as high performance purification steps in biology. Each enzyme requires specific strategy for the purification of individual enzyme (Balasubramanian et al., 2012).

Determination of physicochemical properties of purified enzymeis essential to access the potential of the L-Asparaginase to be used as a therapeutic drug. It is deliberated by $\mathrm{pH}$, temperature and constancy of enzyme in human serum, effect of metal ions, substrate concentration and molecular weight determination (Kumar et al., 2011). The above characteristics are useful in analyzing optimal conditions forthe maximum enzyme activityin purified enzyme. However, due to continuous and complete research, compare to land-based natural compounds, water-based natural compounds have become a more promising source, not only for industrial and commercial applications, but also a pharmacological view (Venkata Siva Lakshmi et al., 2015).

\section{MATERIAL AND METHODS}

Source: Two marine deep water samples from a depth of $10 \mathrm{~cm}$ were collected at Shangamugam and Backwaters of Veli Beach in Kerala state, with a view to isolate effective L-Asparaginase producing microorganisms, as these areas have not been explore formerly in this direction.

Microbial inoculum preparation for optimization: The two microbial strains isolated BKJM1 and BKJM2, were used for optimization studies further. The isolates were maintained on Glycerol Asparagine agar slants at 4-8 ${ }^{\circ} \mathrm{C}$ and sub-cultured once in a month. Spore suspension using $5 \mathrm{ml}$ sterile water containing $0.1 \%$ tritonX was prepared from slant with spores. The count of spores was adjusted to $5 \times 106$ spores/ml by dilution. Ten percentage of spore suspension was added in Erlenmeyer's flask containing Glycerol Asparagine broth. The flasks were kept on rotary shaker and agitated at $150 \mathrm{rpm}$ for $72 \mathrm{~h}$. at $28^{\circ} \mathrm{C}$. After incubation, the cell mass was divided by centrifuging at $1500 \mathrm{rpm}$ for $15 \mathrm{~min}$ and washed twofold with sterilized water and suspended in $10 \mathrm{ml}$ of water.

Influence of carbon source: In order to choose the most appropriate carbon substrate for maximum yield of enzyme activity, experiments were conducted with different carbon sources. Effectof five different carbon sources on L-Asparaginase activity was assayed at room temperature after 72 hrs with two monosaccaharides glucose and fructose and three disaccharides maltose, lactose and sucrose at $0.1 \%$ concentration respectively. Tubes without any carbon source serves as control (Barnes et al., 1977).

Role of nitrogen source on asparaginase activity: The ability of the isolate to use different nitrogen sources was studied. Each nitrogen source is incorporated into the medium at $0.1 \%$ level. The conical flasks were inoculated and incubated at 370C. Results were recorded after 3 days. The growth on each source was compared with that on the un- supplemented basal medium. The Significance of three natural nitrogen sources yeast extract, beef extract and peptone and inorganic nitrogen ammonium sulphate was evaluated on asparaginase activity at room temperature with optimized carbon source and control was maintain without any supplementation (Gunasekharan et al., 1995).

Impact of incubation period on asparaginase activity: Glycerol asparagine agar medium is supplemented with suitablecarbon and nitrogen co substrates and incubated under different time intervals 24-120 hrs. Without any carbon and nitrogen sources serves as a control in this study. OD values were taken for the enzyme activity every 24 hrs time interval at $450 \mathrm{~nm}$ to determine its effect on enzyme activity (Prakasam et al., 2007).

Effect of sodium chloride tolerance on L-asparaginase enzyme production: The ability of certain types of microorganisms to tolerate and to adapt to high concentrations of sodium chloride is well known. This adaptability is particularly marked in organisms found in marine water and salt lake mud. For the determination of sodium chloride tolerance, glycerol asparagines agar medium was supplemented with graded amounts of sodium chloride (1, 4, 7, 10 and 13\%). The above medium was inoculated with suspension of the organism. After incubation for $24 \mathrm{~h}$, the maximum salt concentration supporting growth was recorded (Pridham et al., 1956).

Effect of tempareture on L-asparaginase enzyme production: The effect of tempareture on L-asparaginase production was studied by cultivating the BKJM2at differenttemparetures ranging from 20, 30, 37, 40, 50 and $60^{\circ} \mathrm{C}$ and incubated for $72 \mathrm{hrs}$ (Frank et al., 1997).

Effect of pH on L-asparaginase enzyme production: The effect of $\mathrm{pH}$ on L-asparaginase production was studied by cultivating the BKJM2at differentpH ranging from 4, 5, 6, 7, 8and 9 and all the contents were incubated at $37^{\circ} \mathrm{C}$ for 72 hrs (Manna et al., 1995).

Production profile of L-Asparaginase by submerged fermentation: After achieving optimized conditions of nutritional parameters and physico chemical characters, enzyme production was carried out in submerged fermentation mode. Submerged fermentation was carried out with the active isolates using $250 \mathrm{ml}$ Erlenmeyer flasks. One hundred $\mathrm{ml}$ of glycerol asparagine agar medium was inoculated with $1 \mathrm{ml}$ of three day old culture suspension in each flask. Inoculated flasks were incubated at $30^{\circ} \mathrm{C}$ for 5 days on rotary shaker incubator with 250rpm speed. After incubation, fermentation broth was centrifuged at 10,000 rpm for 20 mins Supernatant obtained was used as crude enzyme preparation. Samples were withdrawn periodically every day for determination of L-asparaginase activity (Maladkar et al., 1993). Enzyme activity was denoted as Units/ml. One unit of L-asparaginase activity is defined as the amount of enzyme required to produce one micromole per min under the conditions of the assay. 


\section{Purification of L-Asparaginase}

1. Ammonium sulphate precipitation: Crude extract filtrate was precipitated by adding ammonium sulfate with constant stirring until 80\% saturation and incubated overnight at $4{ }^{\circ} \mathrm{C}$ to assure that the precipitation had come to completion. The precipitate was separated by centrifugation at $8000 \mathrm{rpm}$ for $30 \mathrm{~min}$ at $4{ }^{\circ} \mathrm{C}$. The protein precipitate was resuspended in $50 \mathrm{mM}$ Tris- $\mathrm{HCl}$ buffer (pH 8.5) and dialyzed against same buffer (Rowly and Wriston, 1951).

\section{Purification by Sephadex G-75 column chromatography:} The chromatographic purification steps were performed in a fast protein liquid chromatography (GE Healthcare, Uppsala, Sweden) with a flow rate of $1 \mathrm{ml} / \mathrm{min}$, temperature of $20{ }^{\circ} \mathrm{C}$ and volume fraction of $0.5 \mathrm{ml}$. The elution of protein was estimated by measuring the absorbance at $280 \mathrm{~nm}$. The dialyzed enzyme was filtered through a $0.45 \mu \mathrm{m}$ membrane filter (Millipore, Billerica, MA, USA) and loaded on to a Sephadex G-75 $1 \mathrm{ml}$ column (GE Healthcare, Uppsala, Sweden) that was preequilibrated with $10 \mathrm{mmol} / \mathrm{L}$ Tris- $\mathrm{HCl}(\mathrm{pH}$ 7.0). The bound enzyme was eluted with the $\mathrm{KCl}$ gradient $1.0 \mathrm{~mol} / \mathrm{L}$, in the same buffer. Fractions containing L-asparaginase activity were pooled, dialyzed against distilled water and concentrated by lyophilisation (Ohnuma et al., 1967).

3. Estimation of protein: Protein was estimated by Lowry method (Lowry et al., 1951). The protein reacts with the Folin Ciocalteau reagent to give a colored complex. The color formed is due to the reaction of alkaline copper with protein as in the Biuret reaction and the reduction of the phosphomolybdate by tyrosine and tryptophan present in the protein. The intensity of the color depends on the amount of these aromatic amino acids and thus varies with different proteins.

Characterization of purified L-Asparaginase enzyme activity: The purified L-asparaginase was used for characterization and evaluation of antitumour activity of the enzyme. The characterization is organized for the activity of enzyme in different $\mathrm{pH}$ and temperature, substrate concentration, metal ions, inhibitors, surfactants, stability of enzyme in human serum, molecular weight determination and determination of enzyme kinetics followed by evaluation of antitumor activity of the enzyme.

1. Effect of temperature on enzyme activity: The effect of temperature on the activity of L-asparaginase was determined according to the method of Frank et al, (1977). In order to determine the effect of temperature on purified L-asparaginase, the enzyme activity was studied at different temperatures ranging from $20^{\circ} \mathrm{C}$ to $60^{\circ} \mathrm{C}$, the enzyme activity was determined under standard assay conditions.

2. Effect of pH on enzyme activity: To determine the effect of $\mathrm{pH}$ on purified L-asparaginase, $0.1 \mathrm{ml}$ of the enzyme solution was mixed with $50 \mathrm{mM}$ Tris-HCL buffer of different $\mathrm{pH}$ from 4 to 9 . The optimum $\mathrm{pH}$ for
L-asparaginase activity studied by the method of Imada et al., (1973).

3 Effect of substrate concentration on enzyme activity: To assess the activity of L-Asparaginase, different substrate concentrations ranging from $0.1 \mathrm{mM}-0.6$ $\mathrm{mM}$ were selected. The substrate was prepared in 50 $\mathrm{mM}$ Tris-HCL buffer at $\mathrm{pH}$ 8.4. The enzyme $(0.1 \mathrm{ml})$ was mixed with substrate and incubated for $10 \mathrm{~min}$ at room temperature and enzyme activity was determined (Distasio et al., 1976).

4 Stability of purified enzyme in human serum: For determination of stability of purified L-asparaginase, the human blood was collected and allowed to clot for $2 \mathrm{hrs}$ at room temperature. The blood was centrifuged at $10,000 \mathrm{rpm}$ for $10 \mathrm{mins}$ and then serum was collected, incubated at $50^{\circ} \mathrm{C}$ for 10 mins to get inactive serum. Enzyme solution $(0.1 \mathrm{ml})$ was added to $0.1 \mathrm{ml}$ of inactive human serum. This mixture was incubated at 370C from 24-96 hrs (Dange and Peshwe, 2006).

5 Determination of molecular weight of the purified enzyme: Molecular weight of purified L-asparaginase enzyme was determined by SDS-PAGE analysis (Laemmli, 1970). Protein samples (prepared in Laemmli buffer followed by boiling at $95^{\circ} \mathrm{C}$ for 5 minutes) were separated on 12\% mini SDS-PAGE gels (Mini-protein II dual slab Cell, bio-rad).

6. Effect of various metal ions, surfactants and inhibitors: Purified enzyme has been pre incubated with different metal ions like $\mathrm{Hg}^{2+}, \mathrm{Fe}^{2+}, \mathrm{Mg}^{2+}$ and $\mathrm{Ca}^{2+}$ at $5 \mathrm{mM}$ concentration (Manna et al,1995). Surfactants such as SDS, Tween 80 were applied at a concentration of $1 \mathrm{mM}$ (Janaina et al., 2006). Whereas inhibitors namely EDTA and 2-Mercaptoethanol at 0.1 mM (Moorthy et al, 2010) respectively. Enzyme activity has been estimated. Activity of the enzyme without any addition serves as control.

7. Determination of enzyme kinetics: The kinetic parameters $\mathrm{Km}$ and Vmax of purified enzyme was calculated by the method of Lineweaver and Burk plot method with different concentrations (0.1-0.6mM) of the substrate, L-asparagine dissolved in 50mM tris HCL buffer ( $\mathrm{pH}$ 8.0). Enzyme activity has been assayed by measuring hydrolysis of substrate under standard assay conditions (Lineweaver and Burk, 1934).

\section{RESULTS}

\footnotetext{
Various stages of optimization for L-Asparaginase production

Effect of carbon sources: Among the five different carbon sources (Sucrose, maltose, glucose, lactose and fructose) tested. Highest L-Asparaginase activity $(8.04 \mathrm{U} / \mathrm{ml})$ is produced by BKJM2 in the medium containing glucose as the carbon source and lowest enzyme activity $(0.24$ $\mathrm{U} / \mathrm{ml}$ ) was reported in the medium containing lactose as carbon source. The values are represented in fig 16 .
} 
Figure 1: L-Asparaginase activity in different carbon sources

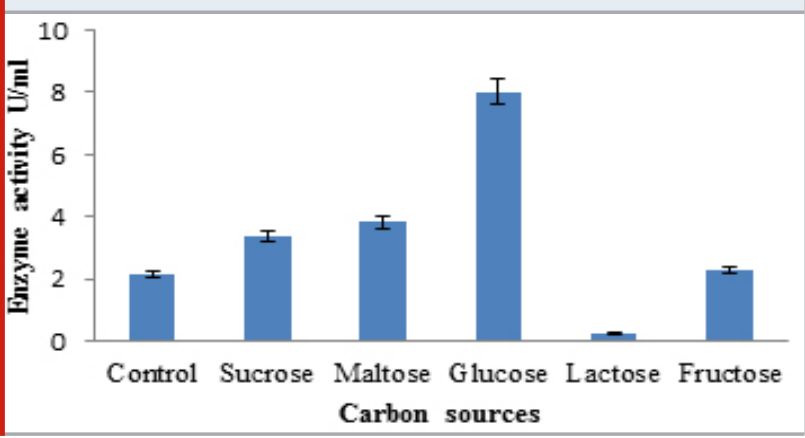

Values are expressed in the mean \pm SD of three independent readings which differ significantly at $\mathrm{p} \leq$ 0.05 .

Effect of nitrogen sources: Impact of different nitrogen sources (yeast extract, beaf extract, peptone and ammonium sulphate) provided maximum L-Asparaginase activity of $5.03 \mathrm{U} / \mathrm{ml}$ produced by BKJM2 in the medium containing peptone as the nitrogen source and least enzyme activity $(1.32 \mathrm{U} / \mathrm{ml})$ was noticed in yeast extract as the nitrogen source, almost equal to that of control fig 17 .

Figure 2: L-Asparaginase activity in different nitrogen sources

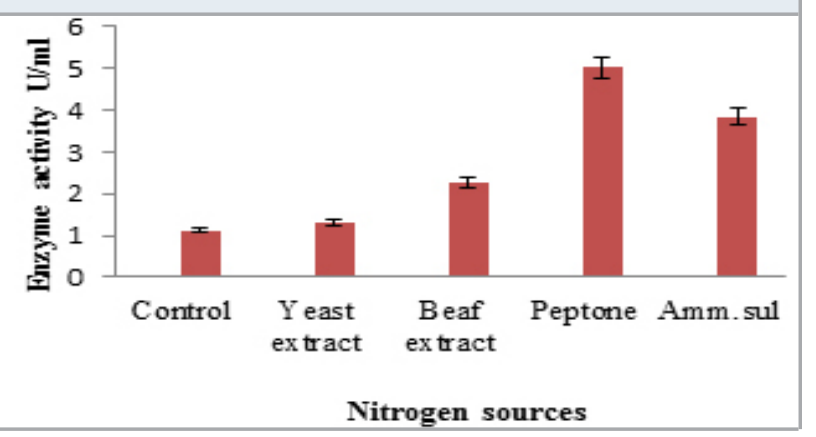

Figure 3: Effect of incubation time on enzyme production

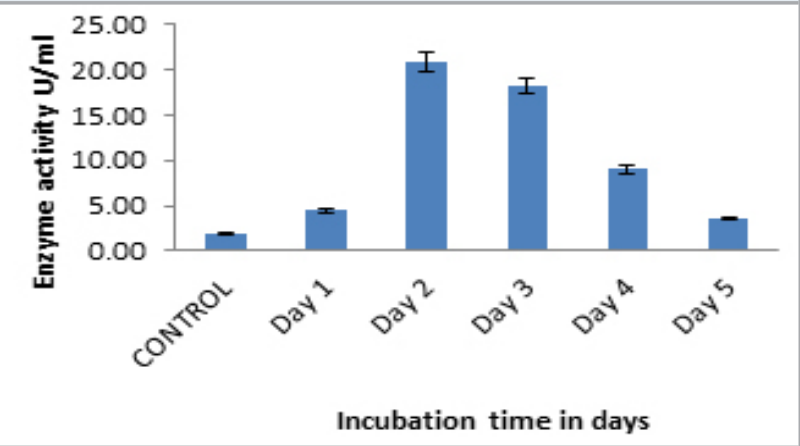

Values are expressed in the mean \pm SD of three independent readings which differ significantly at $\mathrm{p} \leq$ 0.05 .
Effect of incubation time on enzyme production: Influence of incubation time (1-5 days) on enzyme activity was tested. The highest activity $(20.80 \mathrm{U} / \mathrm{ml})$ is observed at 2nd day of incubation and the enzyme activity was declined to $3.60 \mathrm{U} / \mathrm{ml}$ at fifth day of incubation Values are notified in fig 18.

Values are expressed in the mean \pm SD of three independent readings which are different significantly at $\mathrm{p} \leq 0.05$.

Effect of $\mathrm{NaCl}$ concentration on enzyme production: Effect of different $\mathrm{NaCl}$ concentrations (1\%, 2\%, 4\%, $7 \%, 10 \%$ and 12\%) on enzyme activity was tested. The increased activity $(3.90 \mathrm{U} / \mathrm{ml})$ was observed at $7 \%$ concentration of $\mathrm{NaCl}$ (Fig 19).

Figure 4: Effect of $\mathrm{NaCl}$ concentration on enzyme production

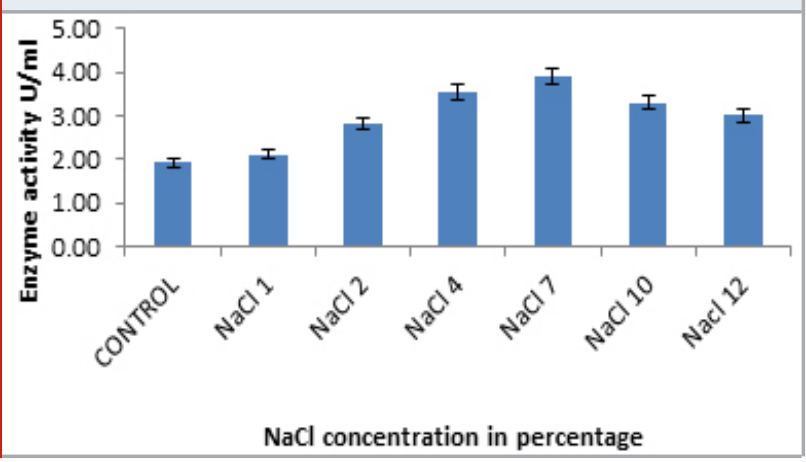

Values are expressed in the mean \pm SD of three independent readings which are different significantly at $\mathrm{p} \leq 0.05$.

Effect of tempareture on L-asparaginase production: Influence of temperature ranging from 20 to $700 \mathrm{C}$ was studied on enzyme activity of BKJM2. The highest activity $(0.73 \mathrm{U} / \mathrm{ml})$ is observed at $400 \mathrm{C}$ of incubation temperature and the enzyme activity was declined with increasing temperature ranges (Fig 20).

Figure 5: Effect of temperature on L-asparaginase production

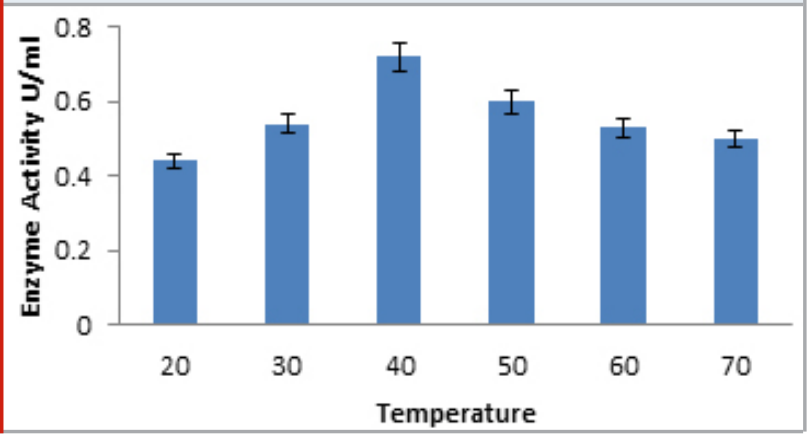

Values are expressed in the mean \pm SD of three independent readings which are different significantly at $\mathrm{p} \leq 0.05$. 
Effect of pHon L-asparaginase production: Impact of $\mathrm{pH}$ was determined at a range of 4 to 9 . The highest activity $(0.38 \mathrm{U} / \mathrm{ml})$ is observed at the neutral $\mathrm{pH} 7$ (Fig 21). Incresing trend was noticed from acidic $\mathrm{pH} 4$ to the neutral range 7. Enzyme activity was declined (0.07 U/ $\mathrm{ml}$ ) as the $\mathrm{pH}$ is increased from 7 to 9 .

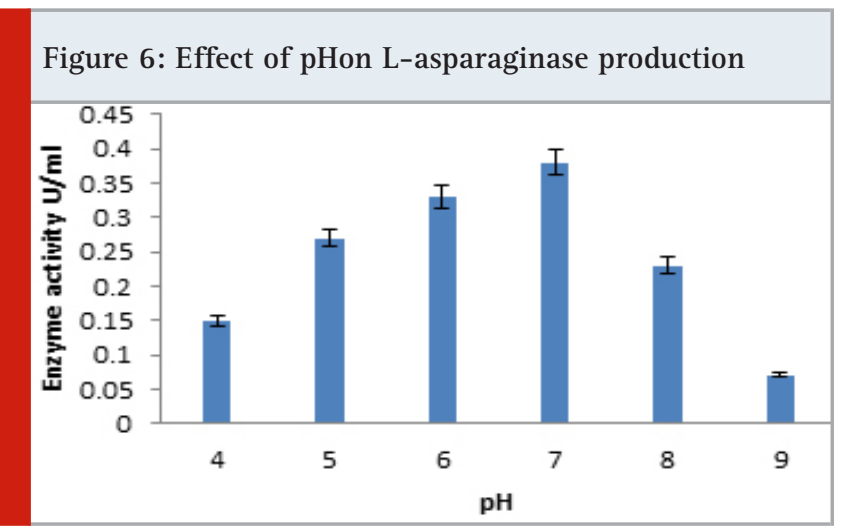

Table 1. Summary of optimal conditions for enzyme production

\begin{tabular}{|l|c|c|}
\hline S.No & Sarocladium kiliense & Enzyme activity U/ml \\
\hline 1 & Carbon sources & 8.02 in glucose \\
2 & Nitrogen sources & 5.03 in peptone \\
3 & Incubation time & 20.80 in $48 \mathrm{hrs}$ \\
\hline
\end{tabular}

Values are expressed in the mean \pm SD of three independent readings which are different significantly at $\mathrm{p} \leq 0.05$.

6 L-Asparaginase activity in submerged fermentation (smf): Optimization of nutritional conditions like carbon, nitrogen sources and incubation time is done in submerged fermentation for L-Asparaginase enzyme activity $(20.80 \mathrm{U} / \mathrm{ml})$.The enzyme activity was illustrated in table 13, for BKJM2.

Table 2. Purification profile of L-Asparaginase enzyme produced by BKJM2

\begin{tabular}{|l|c|c|c|c|c|}
\hline Sample & $\begin{array}{c}\text { Enzyme activity } \\
(\mathrm{U} / \mathrm{ml}) \text { Mean } \pm \text { SD }\end{array}$ & $\begin{array}{c}\text { Protein }(\mathrm{mg} / \mathrm{ml}) \\
\text { Mean } \pm \text { SD }\end{array}$ & $\begin{array}{c}\text { Specific activity } \\
(\mathrm{U} / \mathrm{mg}) \\
\text { Mean } \pm \text { SD }\end{array}$ & $\begin{array}{c}\text { Purification fold } \\
\text { Mean } \pm \text { SD }\end{array}$ & $\begin{array}{c}\text { \% of yield } \\
\text { Mean } \pm \text { SD }\end{array}$ \\
\hline Crude & $366 \pm 2$ & $0.507 \pm 0.006$ & $791.8 \pm 1.80$ & $1 \pm 0$ & $100 \pm 0$ \\
\hline Ammonium sulfate & $356.3 \pm 1.52$ & $0.42 \pm 0.002$ & $845.3 \pm 1.52$ & $1.15 \pm 0.01$ & $95 \pm 1$ \\
\hline Dialysed & $291.1 \pm 1.89$ & $0.31 \pm 0.001$ & $503.1 \pm 1.85$ & $0.07 \pm 0.01$ & $78.8 \pm 0.77$ \\
\hline Sephadex G-75 & $93.7 \pm 0.25$ & $0.183 \pm 0.003$ & $919 \pm 2$ & $1.24 \pm 0.03$ & $24.8 \pm 0.73$ \\
\hline
\end{tabular}

Figure 7: FPLC analysis of L-Asparaginase enzyme

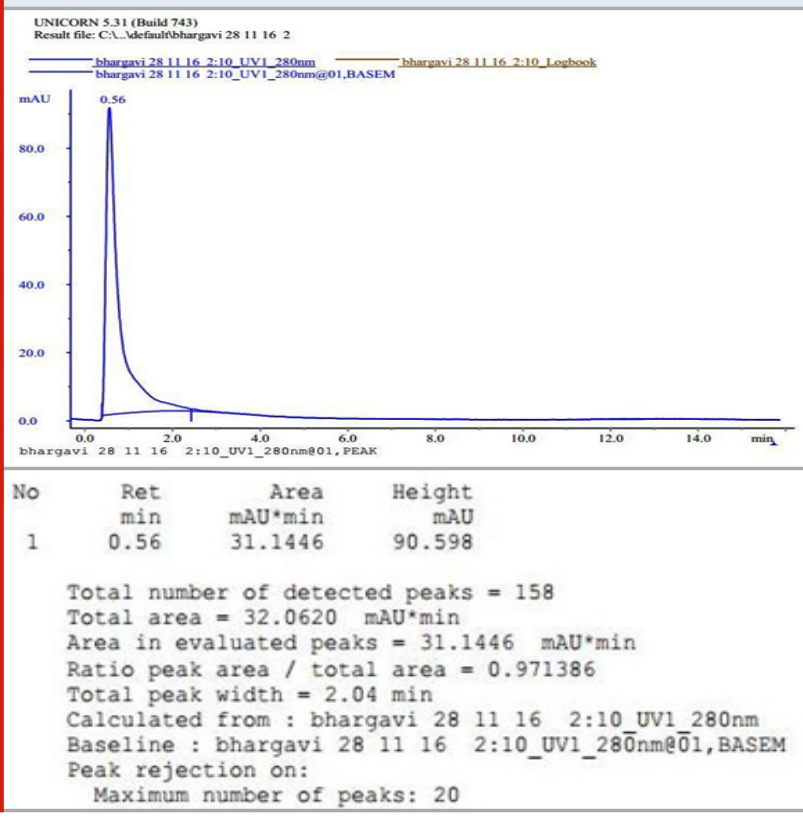

Purification of L-asparaginase enzyme: The purification of L-Asparaginase was carried out in three steps at $4^{\circ} \mathrm{C}$. In purification process the crude extract was affected by ammonium sulfate precipitation (80\%) followed by dialysis. Further the dialysed sample was applied to gel filtration chromatography. The chromatography column was packed with Sephadex G-75 which is connected to fast protein liquid chromatography (FPLC) apparatus and fractions were collected at flow rate of $1 \mathrm{ml} / \mathrm{min}$. The chromatogram of L-Asparaginase was shown in Fig 1. At 0.56 mins retention time, highest peak area and protein concentration $(0.18 \mathrm{mg} / \mathrm{ml})$ was observed. Formation of single peak in the chromatogram indicate purity of the sample achieved by FPLC. The purification profile of the L-Asparaginase enzyme was tabulated in Table 1.

Characterization of purified L-Asparaginase enzyme Effect of temperature on enzyme activity: Effect of different tempareture ranging from $200 \mathrm{C}$ to $60^{\circ} \mathrm{C}$ was tested on the L-Asparaginase enzyme activity. As per the results shown in fig 2, a bell shaped curve was obtained. The maximum enzyme activity $(0.73 \mathrm{U} / \mathrm{ml})$ was noticed at $37^{\circ} \mathrm{C}$. The activity decreased dramatically when the temperature is above $40^{\circ} \mathrm{C}$.

Effect of $\mathrm{pH}$ on enzyme activity: The influence of $\mathrm{pH}$ ranging from 4 to 9 was studied on enzyme activity and the results were incorporated in fig 3 . The highest enzyme activity $(0.39 \mathrm{U} / \mathrm{ml})$ was observed at $\mathrm{pH} 7$ and 
then enzyme activity was decreased to $\mathrm{pH} 9$. As per the above results the enzyme is active at neutral $\mathrm{pH}$.

Effect of different substrate concentrations on enzyme activity: The impact of substrate concentration from 0.1 $\mathrm{mM}$ to $0.6 \mathrm{mM}$ on enzyme activity was illustrated in fig 4. The enzyme shows profound activity $1.39 \mathrm{U} / \mathrm{ml}$ at a substrate concentration of $0.2 \mathrm{mM}$. The enzyme exhibited a typical bell shaped profile covering a broad tempareture range. Enzyme activity is $0.99 \mathrm{U} / \mathrm{ml}$ at a substrate concentration of $0.3 \mathrm{mM}$ and dramatically decreased to $0.72 \mathrm{U} / \mathrm{ml}$ in presence of $0.4 \mathrm{mM}$ substrate concentration and then increased to $1.29 \mathrm{U} / \mathrm{ml}$ at $0.5 \mathrm{mM}$.

Effect of different metal ions, inhibitors and surfactants: Various metal ions, inhibitors and surfactants are used for the determination of L-Asparaginase enzyme activity produced by Sarocladium kiliense. The highest enzyme activity $(2.34 \mathrm{U} / \mathrm{ml})$ was noted with $\mathrm{Fe} 2+$ ions and $\mathrm{Mg} 2+$ ions show reduced activity. $(0.20 \mathrm{U} / \mathrm{ml})$. The inhibitor EDTA displayed $0.24 \mathrm{U} / \mathrm{ml}$ and surfactants SDS, Tween80 reveal $0.42 \mathrm{U} / \mathrm{ml}$ and $0.24 \mathrm{U} / \mathrm{ml}$ of enzyme activity (Fig. 5).

\section{Stability of purified L-Asparaginase enzyme in human} serum: The enzyme was Incubated in human serum at 24 hrs to 96 hrs. The enzyme is relatively stable in this physiological fluid. Maximum activity $(0.28 \mathrm{U} / \mathrm{ml})$ was reported at $48 \mathrm{hrs}$ of incubation. The results were incorporated in fig 6 . This is also indicates that the components of human serum are not much inhibitory towards the enzyme because the enzyme retained its activity even after 96 hrs of incubation.

Figure 849: Effect of temperature $\mathrm{Et} \mathrm{pH}$ on L-Asparaginase activity

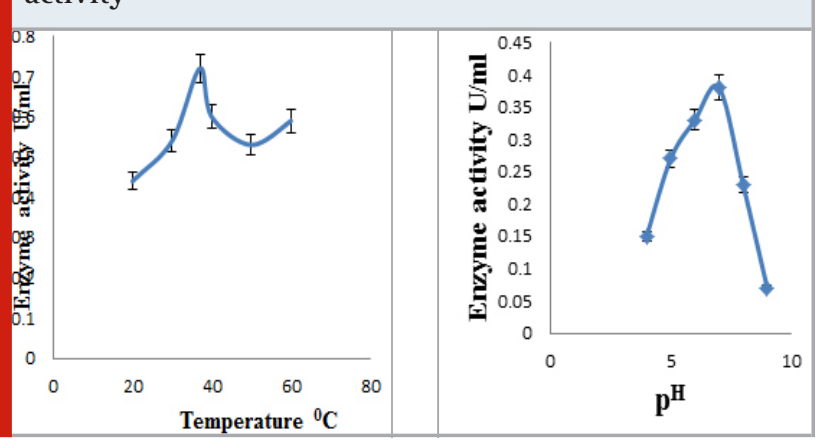

Molecular identification of purified L-Asparaginase enzyme by SDS-PAGE: The active fractions having maximum L-Asparagiase enzyme activity collected from gel filtration chromatography was analyzed through SDS-PAGE analysis. As shown in fig 7 a single band of purified L-asparaginase that coincides with $66 \mathrm{KDa}$ in the protein marker was observed.

Kinetic studies of L-Asparaginase enzyme: The $\mathrm{Km}$ and Vmax of L-Asparaginase enzyme purified from Sarocladium kiliense were determined by using various concentration of L-asparagine.The values of $\mathrm{Km}$ and Vmax were $0.025 \mathrm{mM}$ and $0.30 \mu \mathrm{mol} / \mathrm{ml} / \mathrm{min}$ respectively, which is lower than the $\mathrm{Km}$ value $(0.0598 \mathrm{mM})$ of L-asparaginase purified from Streptomyces radiopugnans MS1.The purified L-asparaginase exhibits stronger affinity towards its natural substrate L-asparagine, a positive property to be useful towards the treatment of tumors. The $\mathrm{Km}$ and Vmax values of BKJM2 was represented in fig 8 .

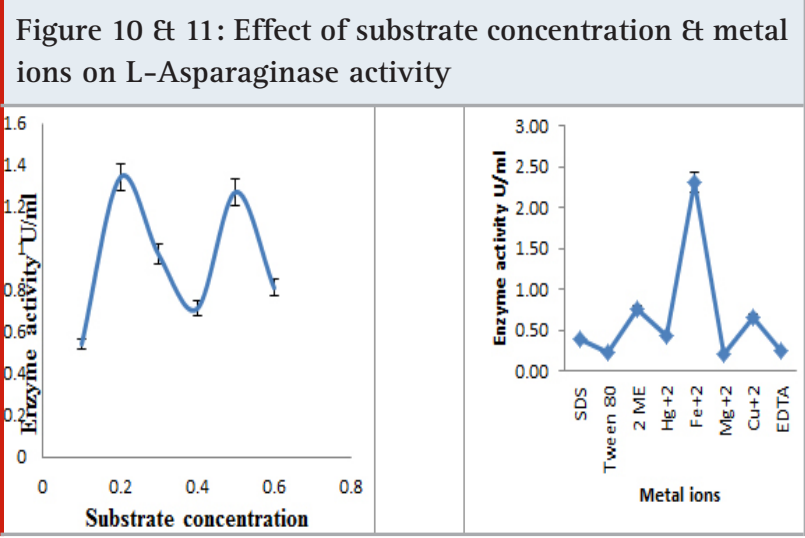

Figure 12 \&t 13: Effect of incubation time on L-Asparaginase activity \& Molecular identification of L-Asparaginase enzyme ( $M=$ Marker, $P F=$ Purified, $D=$ Dialysed)

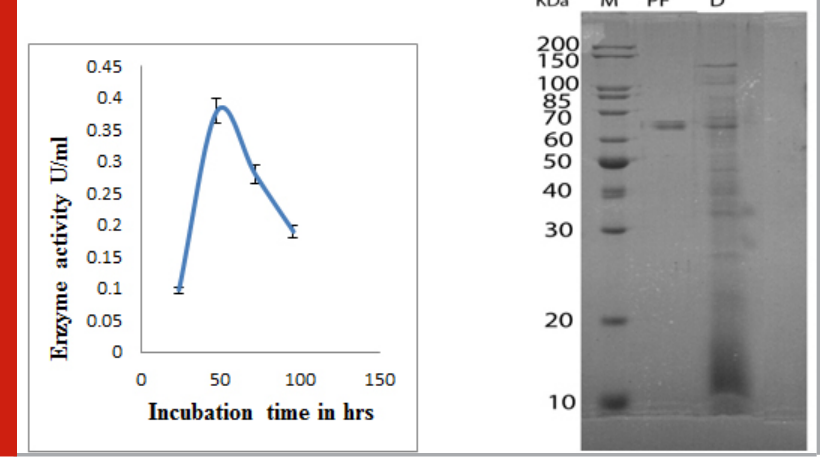

\section{DISCUSSION}

In addition to the soil environment L-Asparaginase production is also observed in many of the marine microorganisms (Sindhwad and Desai, 2015). Marine microorganisms are more advantageous as they have more anti-cancer activity through several mechanisms with fewer side effects to human (Lindequist, 2016). The marine environment is very rich source of potent drugs having broad spectrum anti-tumor property against solid tumors such as Sarcomas and breast cancer (SeKwon Kim, 2014). Moreover the saline nature at sea water is chemically closer to human blood plasma. This contributes to the selective toxicity effect. When BKJM2 was grown on 3 different medias such as starch casein agar, glucose asparagine agar and glycerol asparagine agar maximum growth was observed in glycerol asparagine agar medium. Hence fermentative studies were carried out only with glycerol asparagines agar medium. In order to obtain significant yield of enzyme, 
optimization of carbon, nitrogen, incubation time, $\mathrm{NaCl}$ concentration, temperature $\mathrm{Et} \mathrm{pH}$ was performed.

Figure 14: Kinetic studies of L-Asparaginase

From the above graph $\mathrm{K}_{\mathrm{m}} / \mathrm{V}_{\text {max }}=\mathbf{0 . 0 7 9 5}$

$\mathrm{Y}=0.0795 \mathrm{X}+3.3038 \quad \mathrm{~K}_{\mathrm{m}}=\left(\mathrm{V}_{\max }\right)\left(\mathrm{K}_{\mathrm{m}} / \mathrm{V}_{\max }\right)$

In Y-intercept, 3.3038 is equal to $1 / \mathrm{V} \max$

(0.302681) (0.0795)

Therefore

$\mathrm{V}_{\max }=1 / 3.3038$

$\mathrm{V}_{\max }=0.302681 \mu \mathrm{mol} / \mathrm{ml} / \mathrm{min}$

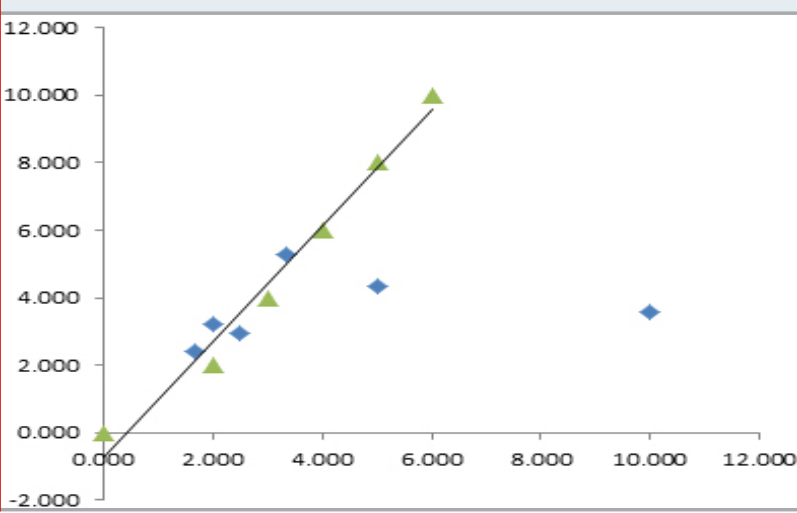

Different carbon sources such as sucrose, maltose, glucose, lactose and fructose were amended to the fermentation medium and results were noted. Glucose monosaccharide showed highest enzyme activity 8.04 U/ $\mathrm{ml}$ followed by maltose $3.84 \mathrm{U} / \mathrm{ml}$ and sucrose $3.36 \mathrm{U} /$ $\mathrm{ml}$. Coinciding with present research findings Mohamad Maharoop Raja et al., (2016), obtained profound increase in enzyme activity $1.58 \mathrm{U} / \mathrm{mg}$ in the medium containing glucose as the carbon source in Micromonospora. Similar results were also noticed by Farag et al., (2015) with Aspergillus terreus. Influence of 3 organic nitrogen sources such as yeast extract, peptone and beef extract as well as one inorganic nitrogen source ammonium sulfate on L-Asparaginase enzyme activity was evaluated and the experimental values were represented. The prominent increase in enzyme activity $(5.04 \mathrm{U} / \mathrm{ml})$ in glycerol asparagines agar medium incorporated with $0.1 \%$ peptone was notified. In accordance with our experimental results highest yield of L-Asparaginase activity $1.76 \mathrm{U} / \mathrm{ml}$ is found in the medium containing peptone as nitrogen source at a concentration of $0.2 \%$ by actinomycetes member Streptomyces ginsengisoli (Neelima et al., 2014).

Effect of $\mathrm{NaCl}$ concentration on L-asparaginase production was also studied by dirretent researchers. The production was inversely related with increasing concentration of $\mathrm{NaCl}$ and found to be maximum $(19.85 \mathrm{IU} / \mathrm{ml})$ at $0.5 \%$ concentration in marine Bacillus sps (Pallavi and Amrutha, 2015). In the present study, $7 \%$ of $\mathrm{NaCl}$ concentration exihibited more enzymatic activity with $3.90 \mathrm{U} / \mathrm{ml}$ was observed in BKJM2. The effect of tempareture and $\mathrm{pH}$ on enzyme production is one of the most important parameter. With the increase in tempareture the enzyme production was decreased. In the present study the BKJM2shows $0.73 \mathrm{U} / \mathrm{ml}$ of enzyme activity in between $300 \mathrm{C}-400 \mathrm{C}$. In contrast to this Wakil et al., (2015), reported $3.3 \mathrm{U} / \mathrm{ml}$ of enzyme activity at 450C in Bacillus circulances. PH also showed marked variation on asparaginase enzyme production. In the present study pH 7 influenced the highest production of asparaginase. Kavitha and Vijayalakshmi tested different ranges from 2 to 10 for the fermentative production of L-asparaginase from Streptomyces tendae. They also reported that $\mathrm{pH} 7$ is the optimum for L-asparaginase production.

Incubation period is one of the most critical parameter in solid state and submerged fermentation. With the increase in incubation period enzyme activity was also enhanced up to 3 days of incubation, due to the availability of substrate. The crude enzyme was analyzed for its activity by submerged fermentation using marine fungi BKJM2. Modified glycerol asparagines agar medium is chosen as the production medium. About $20.62 \mathrm{U} / \mathrm{ml}$ of enzyme activity has been obtained. Similarly Kavitha and Vijaya lakshmi (2010), used modified ISP- 5 broth medium for submerged production of L-Asparaginase. About $4.27 \mathrm{U} / \mathrm{mg}$ of cell dry weight as been produced with strain Streptomyces collinus. The partial purification of L-Asparaginase crude preparation was affected by ammonium sulfate and showed that most of enzyme activity was preserved in the precipitate. The crude enzyme sample is subjected to purification by 80\% ammonium sulfate fractionation. This first step of purification lowered the enzyme activity (368 -356 U/ $\mathrm{ml})$.

Similarly the protein concentration is declined from 0.5 to $0.4 \mathrm{mg} / \mathrm{ml}$. With reference to the specific activity increment was observed. The activity has been enhanced from the initial value 721-847 U/mg. The purification fold is raised 1.17 in the first purification step. Coinciding with first two values, \% of yield has been declined to 96\%. The temperature optimum of L-Asparaginase from Asperigillus terreus KLS2 has shown accelerated enzyme activity at same temperature of $37^{\circ} \mathrm{C}$. The enzyme is active at a wide range of temperature from $30-75^{\circ} \mathrm{C}$. Influence of $\mathrm{pH}$ on L-Asparaginase activity was assessed at different $\mathrm{pH}$ ranging from 4-9 and enzyme activity $(0.38 \mathrm{U} / \mathrm{ml})$ is more prominent at neutral $\mathrm{pH} 7$.

From the graphical representation L-Asparaginase showed the maximum value $(0.99 \mathrm{U} / \mathrm{ml})$ at $0.03 \mathrm{M}$ concentration. The activity slowly declined from $0.3-$ 0.6. Related to this Kamala kumari, (2013) denoted that the enzyme activity was enhanced to the maximum extent $(5.96 \mathrm{U} / \mathrm{ml})$ till $0.07 \mathrm{M}$ substrate concentration in Streptomyces isolated from sea sediments of Tamilnadu. Among the four metal ions tested iron has maximum effect on the enzyme activity $2.34 \mathrm{U} / \mathrm{ml}, \mathrm{Mg}+2$ had minimum influence on L-Asparaginase followed by $\mathrm{Hg}+2$ and $\mathrm{Cu}+2$. With regard to the different inhibitors employed, 2-mepcapto ethanol posses comparatively more activity $(0.78 \mathrm{U} / \mathrm{ml})$ than that of EDTA $(0.24 \mathrm{U} / \mathrm{ml})$. The two surfactants namely SDS and Tween-80 also affected the enzyme activity. The enzyme activity was 
$0.42,0.24$ in the two surfactants tested. Similar data was obtained by Kaliwal and Hosamani (2011).

Furthermore the stability of purified enzyme on human serum was evaluated at different time intervals. The enzyme activity is expressed in $\mathrm{U} / \mathrm{ml}$. The enzyme activity is least $(0.0098 \mathrm{U} / \mathrm{ml})$ at $24 \mathrm{hrs}$ of incubation and reached to the highest level $0.39 \mathrm{U} / \mathrm{ml}$ at $48 \mathrm{hrs}$. Many of the experimental reports indicate molecular weight of L-Asparaginase from 32-150 KDa Archana Rani and Raja Rao (2015) using 12\% resolving gel and 4\% stacking gel. In the present report SDS-PAGE analysis of purified L-Asparaginase enzyme found the molecular weight to be $66 \mathrm{KDa}$ from marine filamentous fungi. It was found that the purified L-Asparaginase is highly specific for L-Asparagine and the $\mathrm{Km}$ values $(0.025$ $\mathrm{mM}$ ) of BKJM2 is lower than $\mathrm{Km}$ value of recombinant E-Coli L-Asparaginase which shows $5.54 \times 10-3$ by the method of Lineweaver Burk plot. The low Km value for the L-Asparaginase isolated in the present study was important in therapeutic rezime (Anil kumar and Savitha, 2015). Because of its low Km value, L-Asparagine has been reported to dose fewer problems during the course of anti tumor therapy.

\section{CONCLUSION}

L-asparaginase from microbial source is of great interest owing to its significance in pharmaceutical and food industries. Therefore, in the present study, Further confirmation of L-Asparaginase activity was accomplished by Imada et al assay method.The yield was 14.62 U/ml in Lactobacillus salivarius and $18.9 \mathrm{U} / \mathrm{ml}$ in Sarocladium kiliense. The potent isolates were subjected to optimization studies by submerged fermentation. Optimization of production parameters such as carbon, nitrogen, incubation period, $\mathrm{NaCl}$ concentration, temperature and pHwas performed. Glycerol asparagine agar medium is found favorable for optimum enzyme activity. Hence remaining fermentation parameters were conducted using the same media. As per the experimental data 3.76 fold enhancement of enzyme yield was found with glucose as the carbon source compare to control. The optimized nitrogen sources $(0.1 \%)$ were peptone with an activity of $5.03 \mathrm{U} / \mathrm{ml}$ which is approximately five times higher than that of control. Maximum increase in the enzyme activity is seen on second day of incubation period. The activity was exaggerated several times higher in comparison with control. Overall the enzyme activity for BKJM1 is $14.62 \mathrm{U} / \mathrm{ml}$ at the end of submerged fermentation.

Approximatly 33 fold improvement in the activity was noticed in sun flower oil cake than without any substrate in solid state fermentation. An attempt is made to purify L-asparaginase from Sarocladium spices and its physical and chemical characteristics were studied. For purification of L-Asparaginase, ammonium sulfate fractionation was found to be highly effective rather than other precipitation agents. Gel filtration chromatography using Sephadex G-75 column further purified L-Asparaginase. Finally overall recovery of $25.4 \%$ of yield, 1.27 fold of purification and a homogeneous form of L-Asparaginase with specific activity of $990 \mathrm{U} / \mathrm{mg}$ was achieved. Studies on physical conditions, which influence the performance of purified L-Asparaginase revealed that the purified L-Asparaginase was active over a broad range of $\mathrm{pH}$ (6-8) and temperature (30-400C). The enzyme is stable at neutral $\mathrm{pH}$. The maximum L-Asparaginase activity was obtained at $\mathrm{pH} 7$, temperature 370C and is quit specific for its natural substrate L-Asparagine.

The apparent $\mathrm{Km}$ value for L-Asparaginase was 0.025 $\mathrm{mM}$. Protein profiling by SDS PAGE confirmed the molecular weight of L-Asparaginase to be $66 \mathrm{KDa}$. Studies on effect of different metal ions, inhibitors and surfactants on the performance of purified L-Asparaginase revealed that several metal ions are detrimental to the enzymatic activity except $\mathrm{Fe} 2+$ and $\mathrm{Cu} 2+$. The enzyme is sensitive to the surfactants (Twee80) and inhibitor (EDTA). The enzyme showed stability in human serum to the maximum of $48 \mathrm{hrs}$ incubation. At $0.3 \mathrm{mM}$ substrate concentration the enzyme activity was increased followed by a declining trend.

Conflict of Interest: Conflict of Interest declared none.

\section{REFERENCES}

Alireza Ebrahiminezhad, Sara Rasoul-Amini, and Younes Ghasemi (2011). L- asparaginaseproduction by moderate halophilic bacteria isolated from Maharloo Salt Lake. Indian Journal of Microbiology 51(3):307311.

Amena, S., Vishalakshi, N., Prabhakar, M., Dayanand, A. and Lingappa, K. (2010). Production, purification and characterization of L-asparaginase from Streptomyces gulbargensis. Brazilian Journal of Microbiology 41(1): 173-178.

Anil Kumar, M. and Savitha J. (2015). Purification and characterization of L-asparaginase therapeutic enzyme from a tropical soil Fungal isolate Fusarium culmorum ASP-87.MOJ Proteomics and Bioinformatics 2(6): $1-6$.

Archana Rani, J. and Raja Rao, P. (2014). Production, purification and characterization of L-asparaginase from Aspergillus nidulans by solid state fermentation. European Journal of Biotechnology and Bioscience 4 (2): 51-58.

Balasubramanian, K., Ambikapathy, V. and Panneerselvam, A. (2012). Production, isolation, and purification of L-asparaginase from Aspergillus terreus using submerged fermentation. International Journal of Advances in Pharmaceutical Research 3(2): 778-783.

Basha, S.N., Rekha, R., Komala, M. and Ruby, S. (2009). Production of extracellular anti-leukaemic enzyme from marine actinomycetes by solid state and submerged fermentation: purification and characterization. Tropical Journal of Pharmaceutical Research 8 (4): 353-360. 
Bhatnagar, P., Scarborough, P., Nigel C Smeeton and Steven Alender (2010). The incidence of all stoke and stoke subtype in the United Kingdom, 1985-2008. A Systematic Review. BMC Public Health, 10 (539): 2731.

Borch, D., Yadav, R.N.S., Ankush, S., Lubana, S. and Anand Kumar C. (2012). Production, purification and process optimization of L-asparaginase (an anticancer enzyme) from E. coli, isolated from sewage water. Asian Journal of Pharmaceutical and Clinical Research 5(3):202-204.

Dange V.U. and Peshwe, S.A. (2011). Production, purification and characterization of fungal L-asparaginase. Bionano Frontier 4(1): 162-167.

Dharmaraj, S. (2011). Study of L-asparaginase production by Streptomyces noursei MTCC 10469, Isolated from marine sponge Callyspongia diffusa. Iranian Journal of Biotechnology 9(2): 17-21.

Dias, F.G.D., Tasca, G.,Della, T. and Helia, H. (2016). Purification, characterization and antiproliferative activity of L-asparaginase from Aspergillus oryzae CCT 3940 with no glutaminase activity. Asian Pacific Journal of Tropical Biomedicine 6(9): 785-794

Distasio, J.A., Niederman, R.A., Kafkewitz, D. and Goodman, D. (1976). Purification and characterization of L-asparaginase with anti-lymphoma activity from Vibrio succinogenes. Journal of Biological Chemistry 251(22): 6929-6933.

Frank, B.H., Pekar, A. H. Veros. Ho P.P.K. (1997). Crystalline from Escherichia coli B. II. Physical properties, subunits, and reconstitution behavior. Journal of Biology and Chemistry 245: 3716.

Gaffar, S.A. (2005). Studies on L-asparaginasefrom Azotobacter vinelandii and Mycobacterium smegmatis, Ph.D. Thesis, IISc, Bangalore:1-251.

Hosamani, R. and Kaliwal, B.B. (2011). Isolation, molecular identification and optimization of fermentation parameters for the production of L-asparaginase, an anticancer agent by Fusarium equiseti. International Journal of Microbiology Research 3(2): 109-118.

Imada, A., Igarasi, S., Nakahama, K. and Isono, M. (1973). Asparaginase and glutaminase activities of microorganisms. Journal of General Microbiology 76: 85-99.

Janaina Nicanuzia dos Prazeres, Juliana Aparecida Bortollotti Cruz and Gláucia Maria Pastore (2006). Characterization of alkaline lipase from Fusarium oxysporum and the effect of different surfactants and detergents on the enzyme activity. Brazilian Journal of Microbiology 37(4): 505-509.

Kamble, V.P., Rao, R.S., Brokar, P.S., Khobragade, C.N. and Dawane, B.S. (2006). Purification of L-asparaginase from a bacteria Erwinia carotovora and effect of a dihydropyramidine derivative on some of its kinetic parameters. Indian Journal of Biochemistry and Biophysics 43: 391-394.

Kotzia, G.A. andLabrou, N.E. (2005). Cloning, expression and characterisation of L-asparaginase Erwinia carotovora. Journal of Biotechnology, 119(4):309-23.

Kumar, S., Venkata Dasu, V. and Pakshirajan K. (2011). Purification and characterization of glutaminase-free L-asparaginase from Pectobacterium carotovorum MTCC 1428. Bioresource Technology 102:2077-2082. Lineweaver, H. and Burk, D. (1934). The determination of enzyme dissociation constants. Journal of American Chemical Society 56: 658-666.

Manivasagan, P., Venkatesan, J., Sivakumar, K. and Kim, S.K. (2013). Marine actinobacterial metabolites: Current status and future perspectives. Microbiology Research 168: 311-332.

Manna, S., Sinha, A., Sadhukan, R. and Chakrabarty, S.L. (1995). Purification, characterization and antitumor activity of L-asparaginase isolated from Pseudomonas stutzeri MB-405. Current Microbiology30: 291-298.

Monica Thakur, Lynette Lincoln, Francois N Niyonzima and Sunil S More, (2013). Isolation, purification and characterization of fungal extracellular L-asparaginase from Mucor hiemalis.World Journal of Proteomics and Enzymology 2(2): DOI-10.4172/2324-9099.1000108.

Moorthy,V., Aishwarya Ramalingam, Alagarsamy Sumantha, Rajesh and Tippapur Shankaranaya (2010). Production, purification and characterisation of extracellular L-asparaginase from a soil isolate of Bacillus sp. African Journal of Microbiology Research 4(18): 1862-1867.

Nagarethinam, S., Nagappa, A.N., Udupa, N., Venkata Rao, J. and Meenashi Vanathi, B. (2012). Microbial L-asparaginasesand its future prospects. Asian Journal of Medical Research 1(4): 159-168.

Ohnuma, T., Bergel, F. and Bray, R.C.(1967). Enzymes in Cancer.Asparaginase from chicken liver. Journal of Biochemistry and Molecular Biology 103: 238-245.

Patro, K. R., Uday Chand, B., Ajay Kumar, M. and Nibha Gupta (2012). Development of new medium composition for enhanced production of L-asparaginase by Aspergillus flavus. Journal of Environmental Biology 35: 295-300.

Pieters, R., Stephen, P. Hunger, Joachim Boos, Carmelo Rizzari, Lewis Silverman, Andre Baruchel, Nicola Goekbuget, Martin Schrappe and Ching-Hon Pui (2011). L-asparaginase treatment in acute lymphoblastic leukemia. American cancer society 117(2):238-249.

Rowley, B. and Wriston, J.C. Jr. (1951). Partial purification and antilymphoma activity of Serratia marcescensL-asparaginase. Biochemical Biophysical Research Communication 28(2):160-165. 
Sahu, M. K., Sivakumar, K., Poorani, E., Thangaradjou, T. and Kannan, L. (2007). Studies on L-asparaginase enzyme of actinomycetes isolated from estuarine fishes. Journal of Environmental Biology 28: 465 - 474.

Se-Kwon Kim (2014). Marine cosmeceuticals. Journal of Cosmetic Dermatology 13(1): 56-67.

Shah, A.J., Karadi, R.V. and Parekh, P.P. (2010). Isolation, optimization and production of L-asparaginase from Coliform Bacteria. Asian Journal of Biotechnology 2(3):169-177.

Sindhwad, P. and Desai, K. (2015). Media optimization, isolation and purification of $\mathrm{L}$-asparaginasefrom marine isolate. Asian Pacific Journal of Health Sciences 2(3):7282.
Sivagurunathan, N., Nagappa, A.N., Udupa, N., Rao, V.J. and Meenash, B. (2012). Microbial and its future applications. Asian Journal of Medical Research 1:15968.

Tundisi, Diego F. Coêlho, Beatriz Zanchetta, Patricia Moriel, Adalberto Pessoa Jr.and Elias B. Tambourgi (2017). Purification of L-asparaginase from mangrove soil.Journal of Separation and Purification Review 46(1):35-43.

Venkata Siva Lakshmi, T., Siva Mallika, D., Jeevan aoms, S. and Kasturi, K. (2015). Marine L-asparaginase: A Novel Microbial Therapeutic Approach for Cancer. International Journal of Pharmaceutical Science Review Research 32(2): 228-234. 